\title{
Anthrovision
}

Vaneasa Online Journal

$3.1 \mid 2015$

Varia 3.1

\section{Under a Blue Sky - Part 2}

Participation and Mourning in Cambodia, an Autobiographical Approach

\section{Ella Pugliese}

\section{(2) OpenEdition}

Journals

Electronic version

URL: http://journals.openedition.org/anthrovision/1502

DOI: 10.4000/anthrovision. 1502

ISSN: 2198-6754

Publisher

VANEASA - Visual Anthropology Network of European Association of Social Anthropologists

\section{Electronic reference}

Ella Pugliese, « Under a Blue Sky - Part 2 », Anthrovision [Online], 3.1 | 2015, Online since 15 December 2015, connection on 30 April 2019. URL : http://journals.openedition.org/anthrovision/1502 ; DOI 10.4000/anthrovision. 1502

This text was automatically generated on 30 April 2019.

(c) Anthrovision 


\section{Under a Blue Sky - Part 2}

Participation and Mourning in Cambodia, an Autobiographical Approach

\section{Ella Pugliese}

Anthropology that doesn't break your heart

is not worth doing

Behar 1996: 177

\section{Going Back - Thnol Lok}

1 As we arrived in Thnol Lok in 2012 the strong sense of the surreal which I had been feeling since our plane landed in Phnom Penh one week earlier became stronger. What a beautiful light was welcoming us in the village, how warm and sweet to see the old women and accept their condolences, how sad, how complicated, and how funny too. "You look as young as three years ago, but fatter!" they told me. And everyone, every single person who talked to us, was stunned at Anouk and kept repeating: "Bai cinam, 3 years... she is so big now!" and I was replying, "Well, now she is 6 - double the age, double the size!" These short conversations took place half in Khmer, half in English, but always with a lot of universal gesture language - what was particularly easy was pointing at Anouk with my hands: now she is SO big, 3 years ago HALF SO big... 


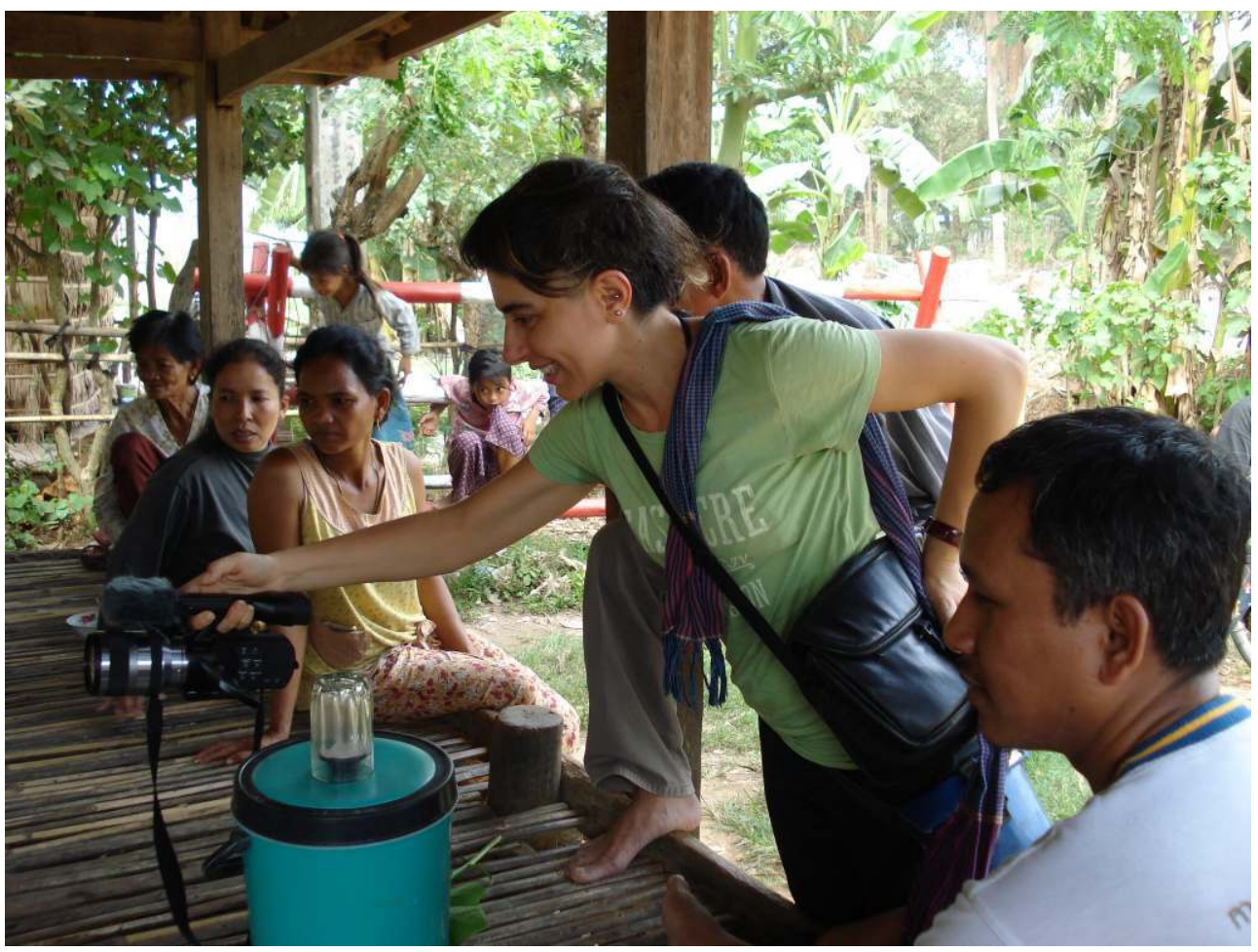

Photo by Judith Strasser (2012)

2 We were filming, Va and I, most of the time. It is so curious to watch this material. It is the same place, often the same light, and the same people like in those days... but something is missing. Not only Jens, but also the village chief who died shortly after, who had supported us very much back then even though he was already sick. And some of the participants were no longer living there. Our village cameraman had had to leave. He was a forest guard, and his political position in the land disputes in the village had resulted in his displacement, they told us. He had been very engaged in our project too, and we were sad to hear of his struggle and that he had had to leave. Even the young cameraman, Kakkda, had gone to work in Thailand, somebody said. What a nice surprise it was to see him later, cycling around. He had just came back for Khmer New Year, one of the major Khmer holidays, which would take place the following week. This made me particularly happy, as Kakkda was one of the people who had had a special bond with Jens. I approached him to give him a big hug - but he was around 18 now, a young man, very shy, far too shy to hug an older foreign woman. And he had forgotten all his English. At the time of filming he was going to school and he was able to communicate with us somehow - now he was working on construction sites on the border with Thailand where English is not needed. Nevertheless it felt very good to have him there. Kakkda and Peppo had always been with us, Peppo was the little deaf-mute boy who was living at the temple and had no name, everybody was calling him simply XXXX ${ }^{1}$. He approached Jens and started to follow him around, taking care of cameras and tripods, having a look at Anouk... Jens developed quickly a 'mute' friendship with him, and Anouk started to call him Peppo', Peppo and Kakkda were part of our film team, but also the two persons in the village whom Anouk trusted the most, and they often took her around as we were filming and needed silence, or took it in turns, one staying with us, the other with her. People told us 
Peppo was still living at the temple and staying at some villagers' houses now and then, so I was certain that he would simply show up as soon as he had understood that we were there. But I was wrong, he never did.

Peppo

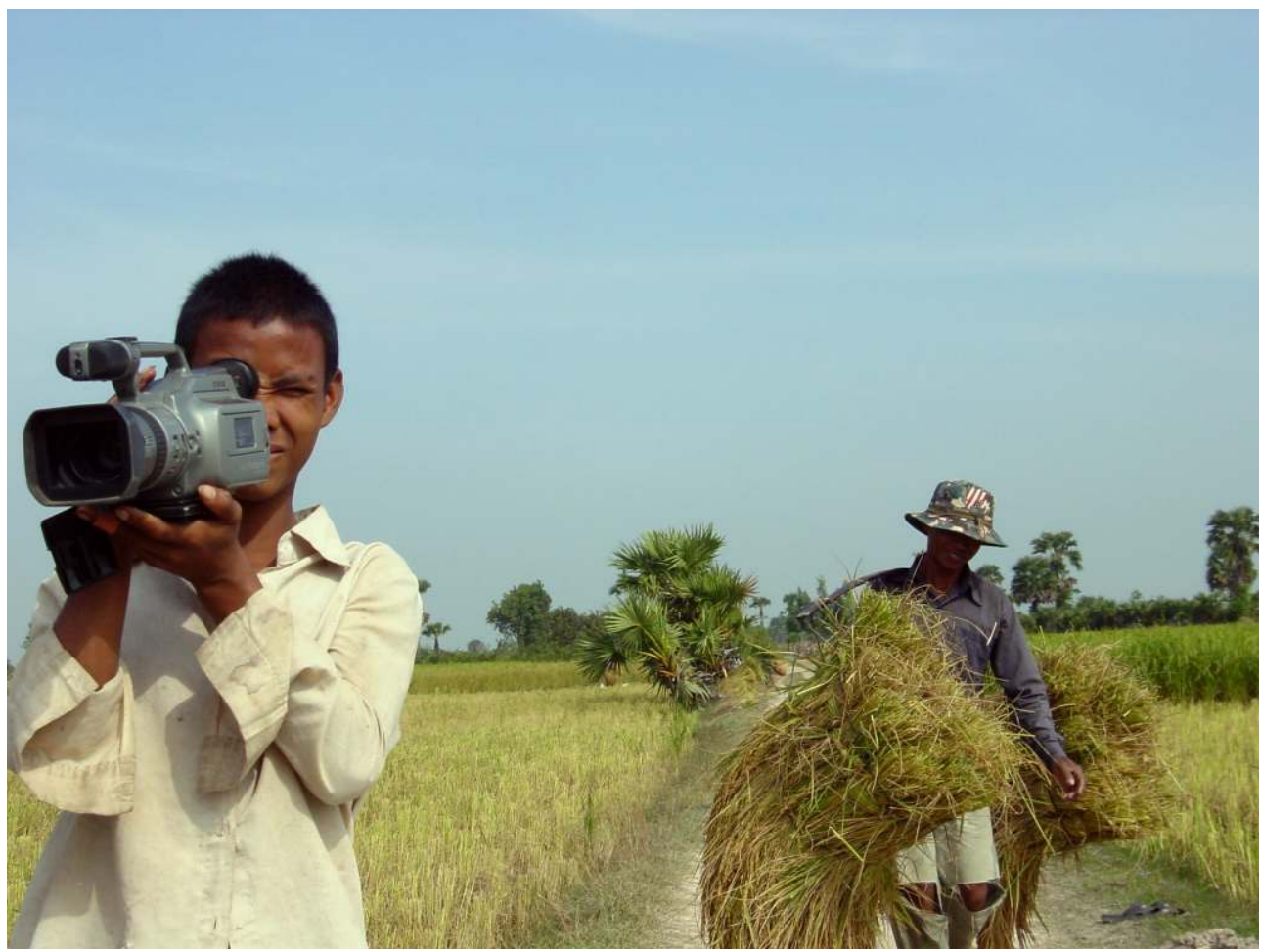

Photo by Julian Poluda (2008)

In the afternoon we went to visit Grandma Nhey, one of the main protagonists of our film, the thin, fragile woman, blind in one eye, and she was very surprised and happy to see us again. We were so happy to hug her, and to see that she had a young couple (her 'grand cousins') taking care of her, so that she was no longer alone. Like some other grandmas, she said that what had happened to Jens was terrible, and that "we are same same now, you suffer, I suffer, we share the same fate". It did not surprise me at all that the old women could be so direct with me. I also felt a different connection between us now. I knew that it would be emotionally overwhelming to see them again and to look in their eyes, now that I was - that I am - a woman who also had suddenly lost her beloved man. It was a little confusing indeed, to feel both 'same same' and different at once, and to draw a parallel line between us while I knew very well that the horror they had known was not comparable to my story ${ }^{3}$. But this time they were 'including' me, they were welcoming me back and giving me their acknowledgement - for they knew that there is a personal and a shared dimension in grief. Like the main protagonist of Ruth Behar's latest storytelling, this example of empathy and solidarity shows us "how to think of history in a new way, where the burden of remembrance is shared." (Behar 2003: 11). 


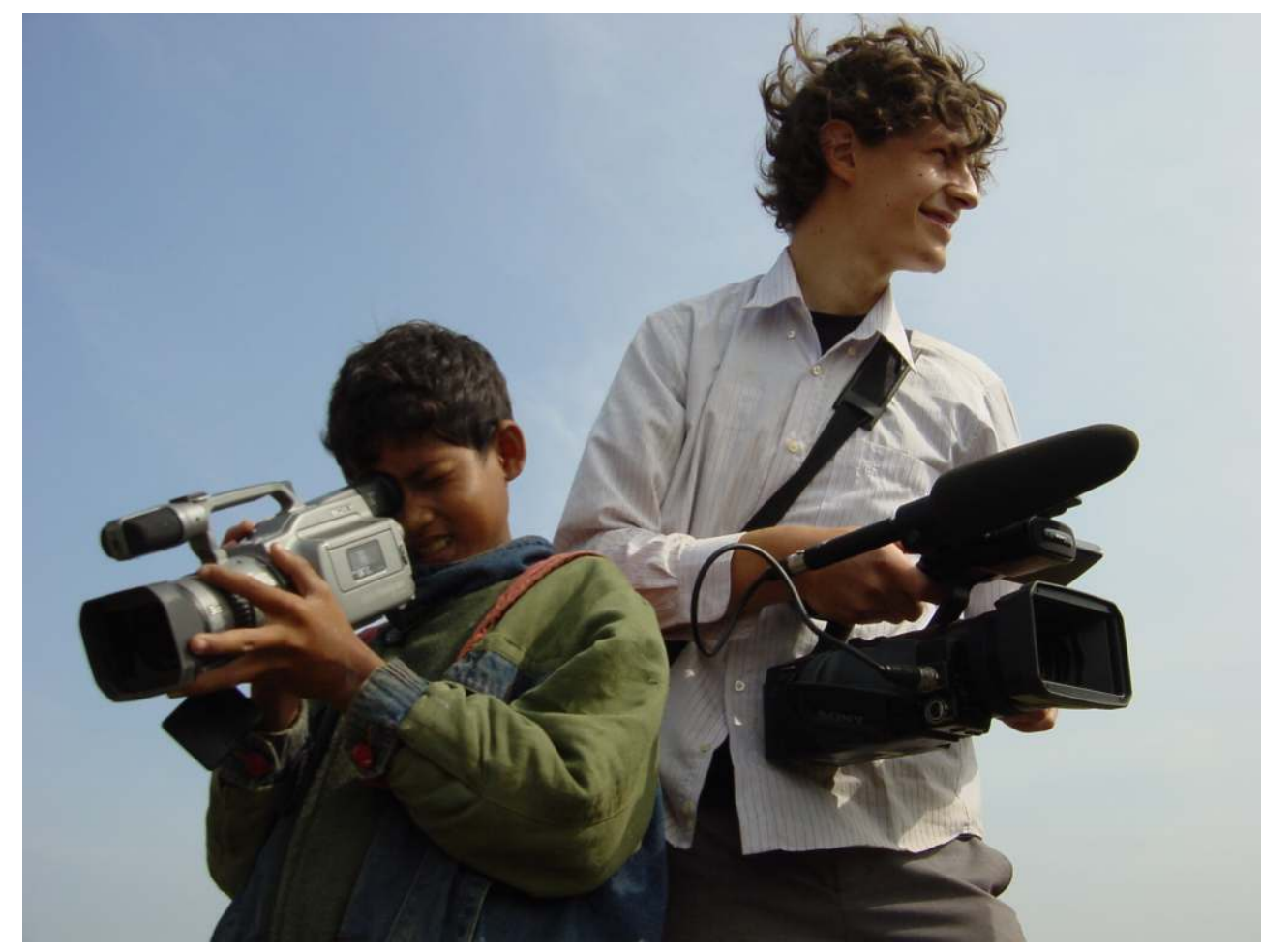

Photo by Julian Poluda (2008)

4 At night we held the film screening. It was a kind of flashback: during WWU2K we had prepared the screen between trees with the help of Peppo and other villagers almost every night, and showed documentaries about the Khmer Rouge and fiction films as well as what we'd just filmed. It was great fun for everybody to see friends, relatives and neighbours on the big screen! Every night the magic of cinema brought all the villagers together. We realized that this event not only offered entertainment but also created a new space - a physical and an emotional one - to share memories. Here even more than in the pagoda scene, people reacted by laughing loud to the re-enactments although, and maybe also because, they were watching some villagers dressed as the terrible Khmer Rouges and others being taken away and executed. It is always great fun to see yourself and others you know up there, especially if you are at all not used to cinema and cameras. But what emerged once again from these experiences was the cathartic power of laughing together, as if through laughing one could partially reduce the pain and retrospectively neutralize, at least for some moments, the terrible past. 


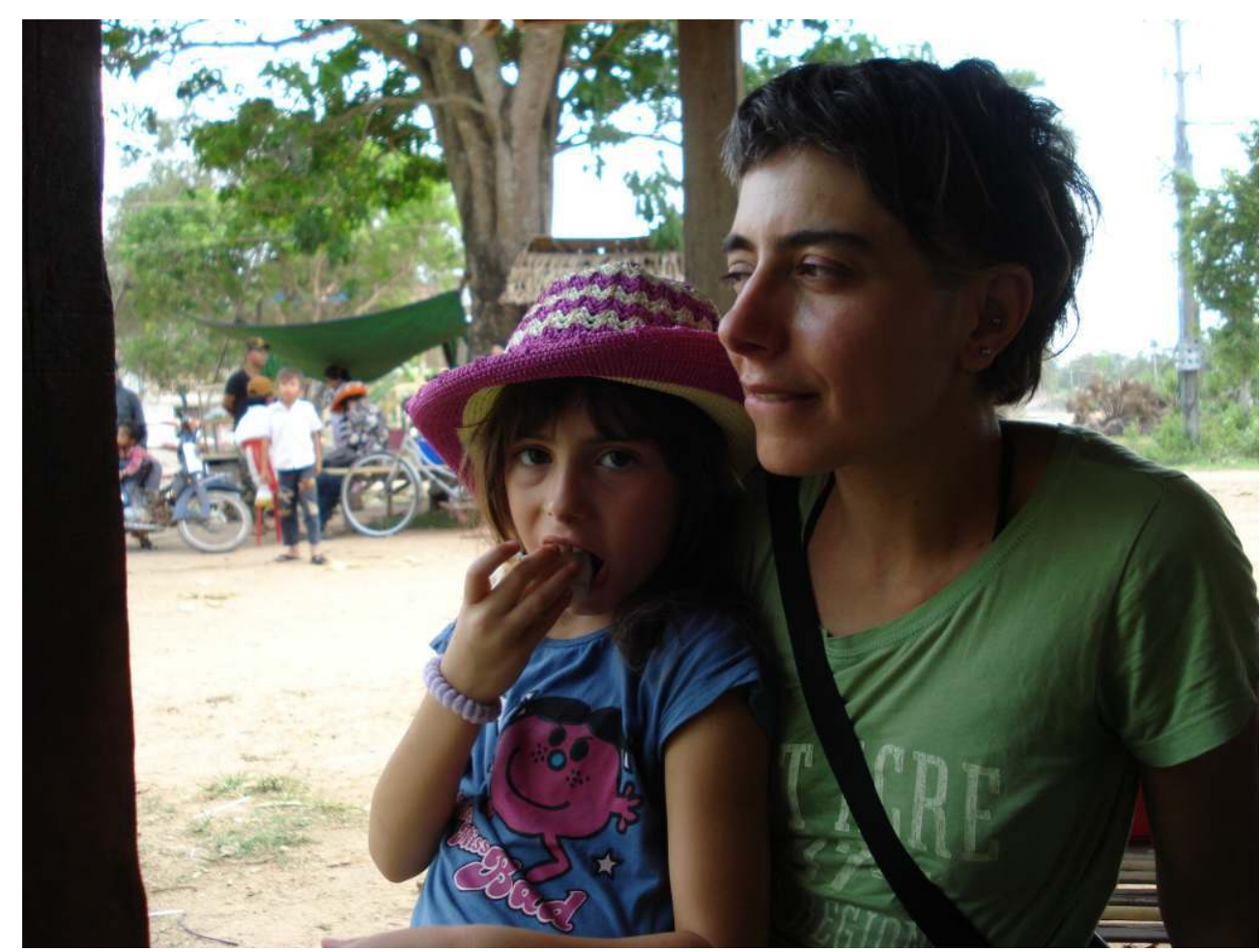

Photo by Judith Strasser (2012)

5 For me... it was very strange indeed to stand there now and show the film for the first time after... everything ${ }^{4}$. I tried to say something like how happy Jens would have been to be with us tonight. I have no idea how and what my colleagues were able to grasp; it did not feel that I could reach the audience at that very moment. At the end of the film there is a little homage to the process behind the film, a 'making of ' with funny moments of all the participants, including us, the barang ${ }^{5}$ with a very little Anouk. But the making of is part of the credits, so most people were starting to go and we had to stop them, both credits and people, because we wanted to have an exchange after the screening. All this left me feeling hollow and unhappy. I would have loved to have shared these pictures with them. There was no time to think about it, anyway, so we organized a little Q\&A round, and I was trying to film fighting against the usual technical difficulties of chaotic moments in the field, such as loud sound and low light.

6 The day after I woke up with fever, diarrhoea, my period, and the strongest allergy attack in months - where we were staying was very dusty, especially at this time of the year when rains still has to come, temperatures are at their peak and everything is incredibly dry. The plan for the day was to go around, talk with people about the project and screening, and to conduct some more interviews. Another task was to prepare the Buddhist ceremony in Phnom Plet pagoda for the following day. During our preparatory meetings in Phnom Penh we had already decided that, as a film team, we would like to conclude our visit there with a ceremony in memory of all our dead, and end by planting a sacred tree as a symbol of remembrance and hope. Now some members of the staff had to talk with the monks, the Acha ${ }^{6}$, and the villagers and to decide together what needed to be done and how. 
7 Although I was feeling increasingly ill, I made a big effort and even managed to film a little. But my body reminded me not to overstretch myself, a very crucial insight when working on something which touches us deeply, an insight that Jens and I had underestimated at the time. So I took some time off during the second day, and I lay down and remembered. Jens had started to feel unwell here at the village in December 2008. He probably already had dysentery, but we did not know that. He was often exhausted and had to rest in between shoots; we had a tough schedule, working hard from early morning till night, so there was seldom time to rest. Now, years later, I lay down, in the same wooden house where we had stayed at the time, and I asked myself what I was doing there, why I was there, feeling hot, shaky, disoriented and sad. I rested a bit and then I stood up because I wanted to visit and film Grandma Nhey again, I wanted to see Kakkda and his friend $\mathrm{Ra}$, the little boy who interviews Grandma Nhey in the film and looks like a little smart student. He had just come back for Khmer New Year, and like Kakkda he had become tall and thin but with exactly the same child's face, the smart student with the white skirt. I did manage, but at some points I stepped back and let the others film and speak, and it was very good indeed.

\section{Our hut in Thnol Lok}

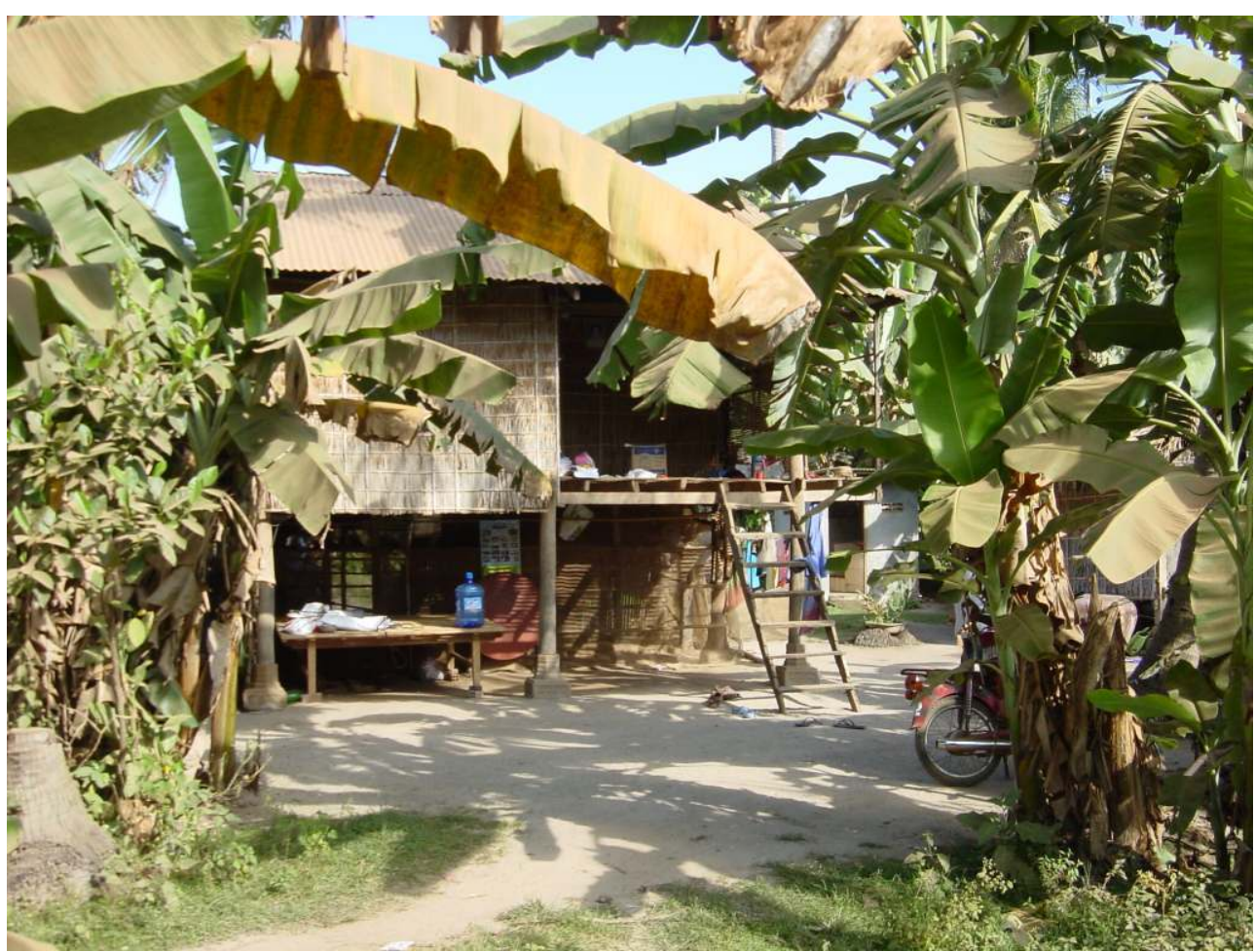

Photo by Julian Poluda (2008)

The third day I realized that I was not unwell, but 'Thnol Lok-sick'. I felt a little bit better, but terribly sad. It was incredible to sit in the pagoda with Anouk among the old women, to listen to the prayers and receive the ceremonial offering in my hands so that I could offer it myself to the monks. I thought: this part of the ceremony is not for us, as we are not Buddhist. But I did feel included again, and I did feel that people were remembering Jens too, and they were doing it with us. It was surreal and painfully real. I was connected and disconnected with the situation, with the old women, with the pagoda and with my colleagues. I knew that we were being filmed, and I felt this time as if I was in the focus 
together with my little one who was sitting there with eyes wide open, asking me about the meaning of the ceremony. I could not give her exhaustive or completely coherent answers. I felt overwhelmed, and finally, I did not know?

Ella and Anouk with the Grandmas during the Buddhist Ceremony

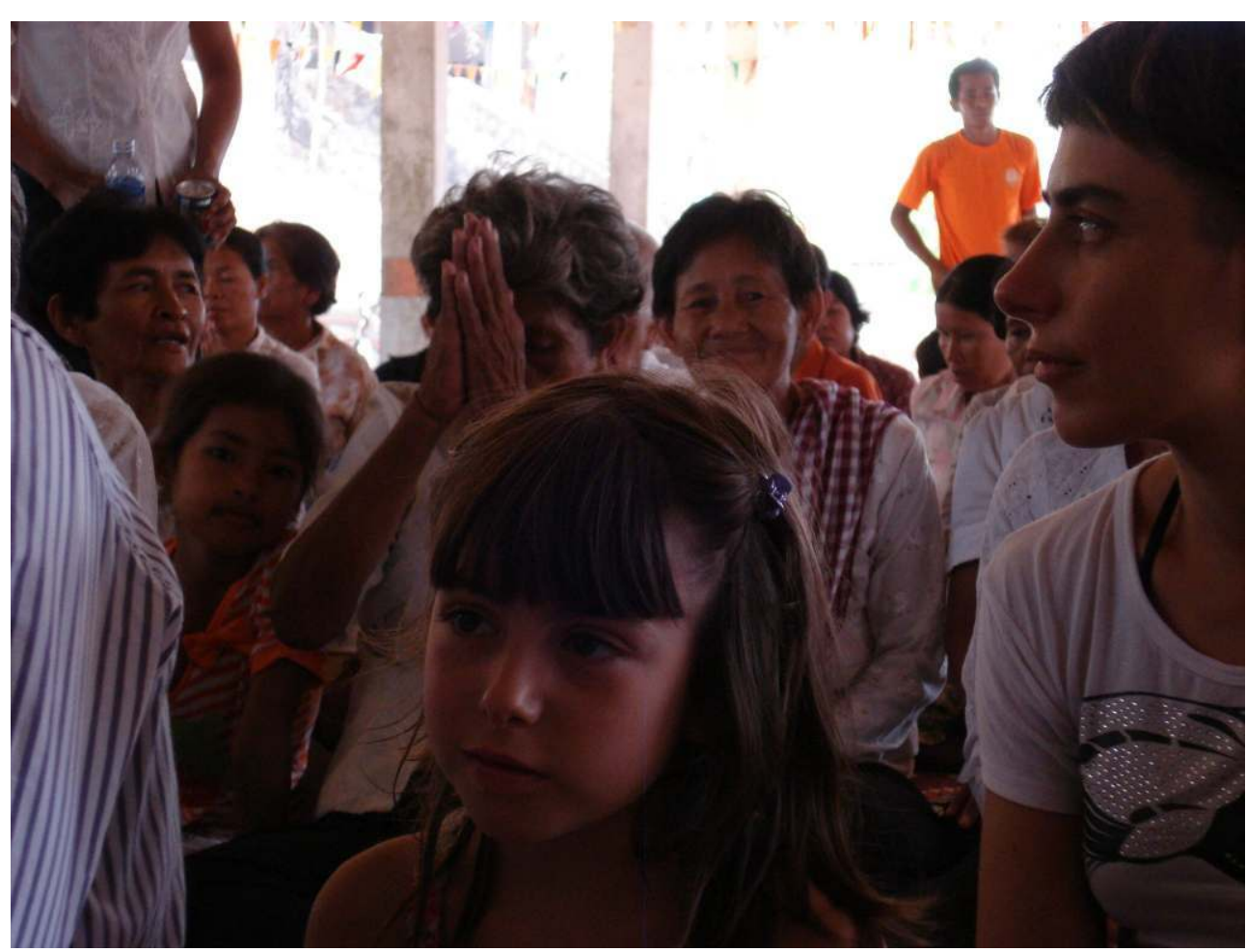

Photo by Judith Strasser (2012) 
Ella and Anouk with the Grandmas during the Buddhist Ceremony

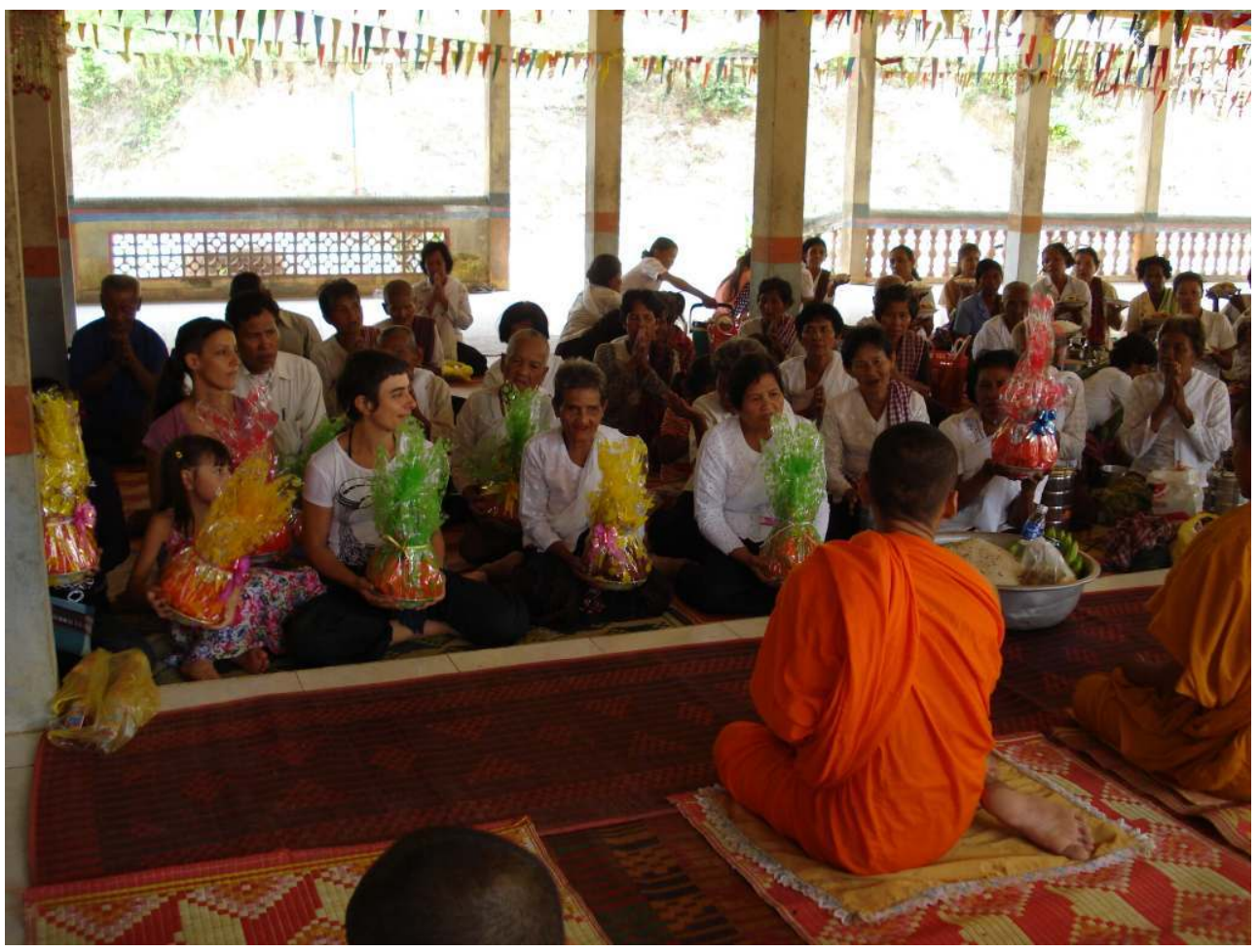

Photo by Judith Strasser (2012)

9 As we left the pagoda to reach the place where it had been decided to plant the bodhy trees $^{8}$, I felt relieved when I realized that Ra and Kakkda were waiting for us. They helped to get baskets of fresh earth and to dig the holes. 
Moments of the ceremony
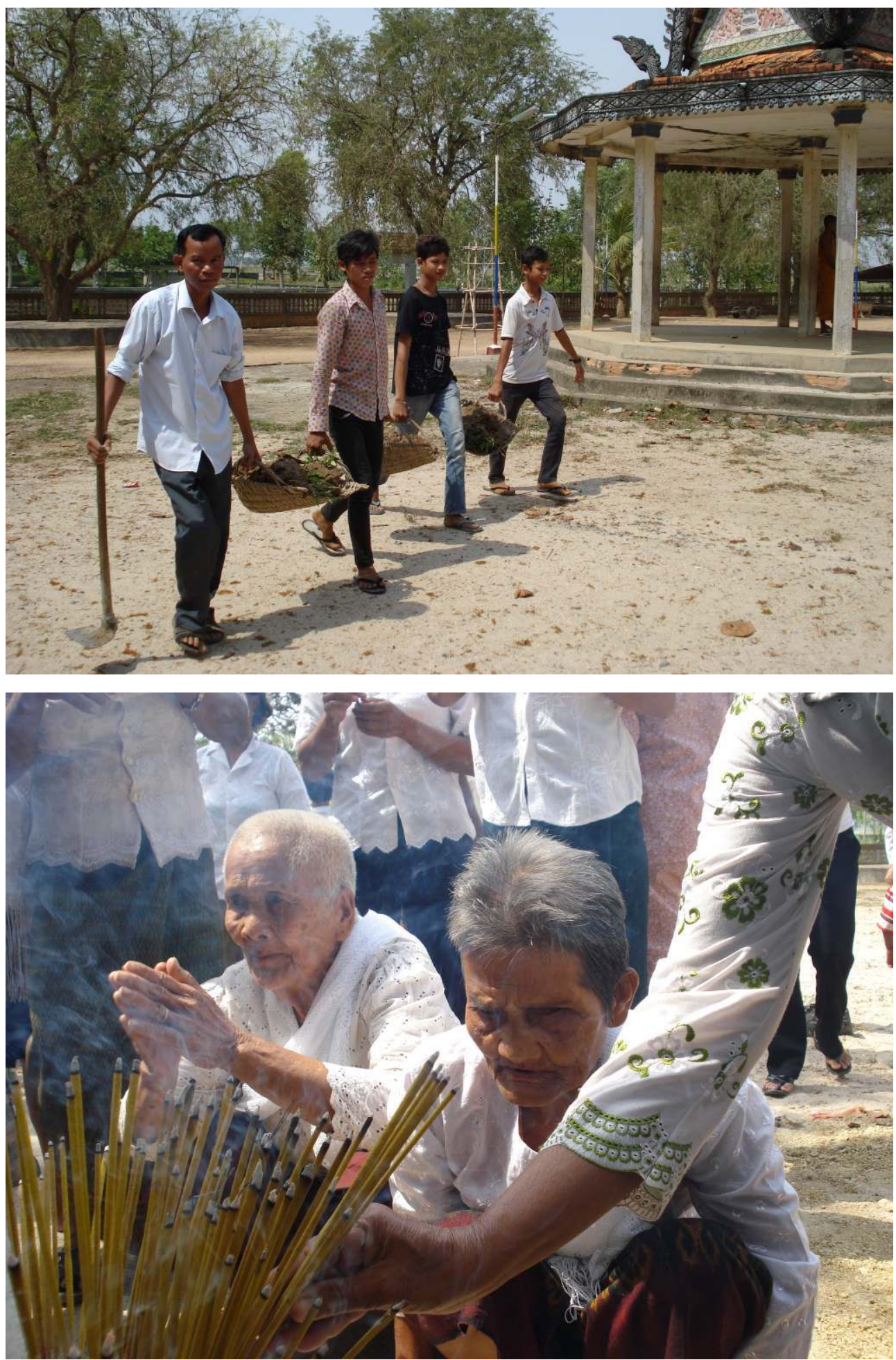

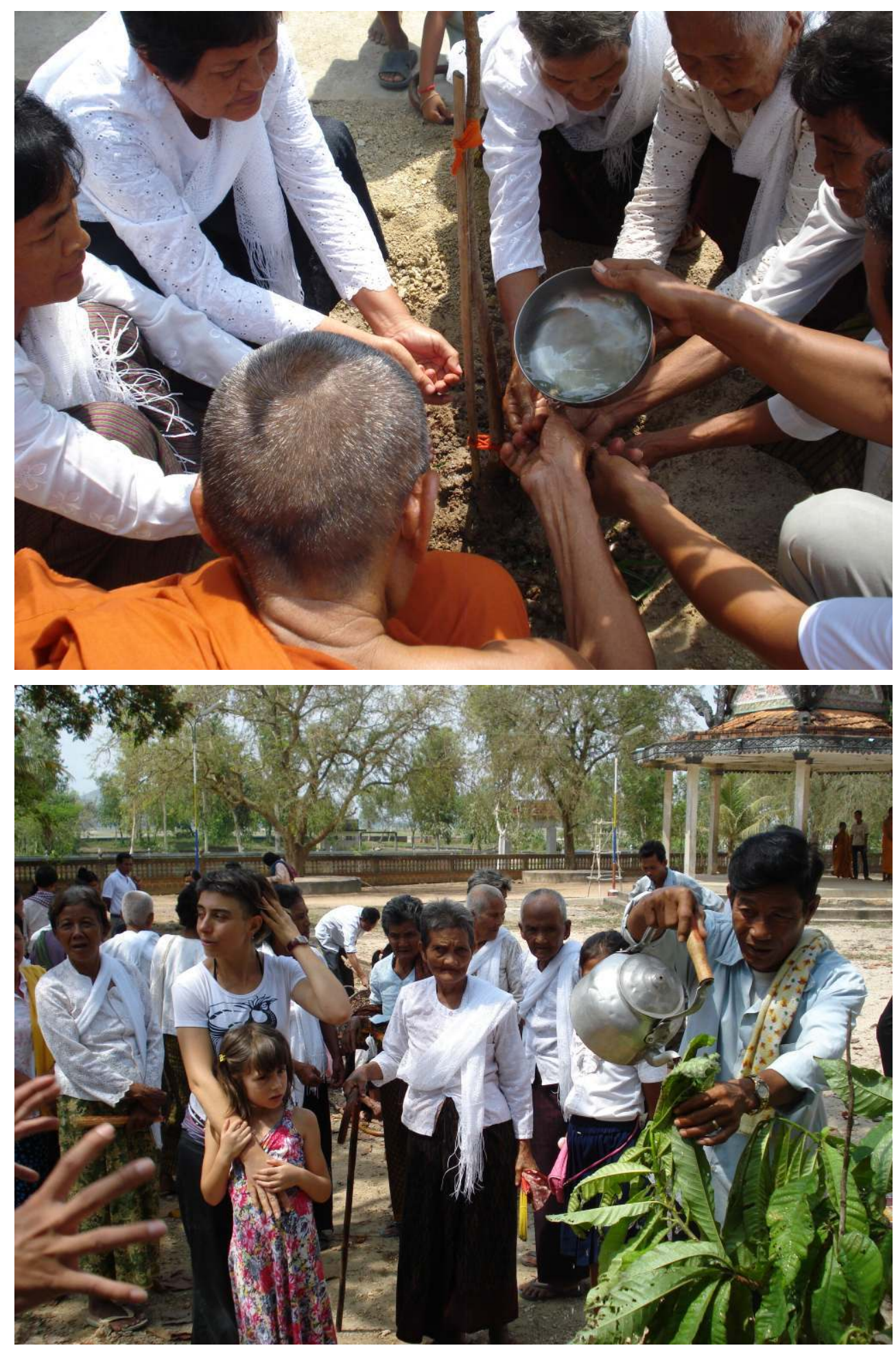

Planting the bodhy trees

Photos by Judith Strasser (2012) 
This media file cannot be displayed. Please refer to the online document http:// journals.openedition.org/anthrovision/1502

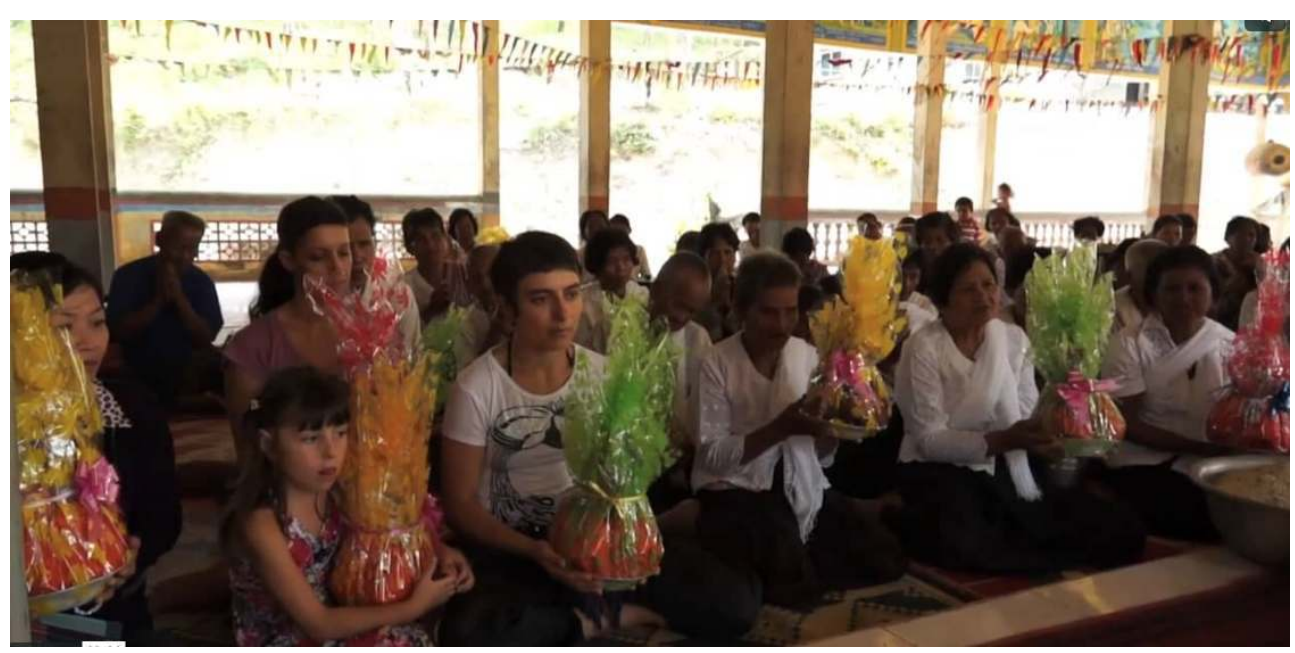

Link: https://player.vimeo.com/video/141045675

Video extract by Ella Pugliese (2015) from We Want (U) To Know by Ella Pugliese, Nou Va and the villagers (2009)

This moment was maybe the most intense and difficult for me. I remember the crowd in front of the stupa as somehow disturbing. Everybody was lighting incense sticks. I tried too, but kept on burning my fingers and my eyes. I renounced but felt lonely among so many people. The Acha approached me and said: "How terrible, you came here the three of you, you went back only two". His gesture touched my heart - pain and relief again -because his words were a sign of solidarity. I followed the silent work of the youngsters together with our Cambodian colleagues. The holes were done, I was called in front again as I was supposed to throw earth around the first young bodhy tree with Anouk.

I did not think of it in this moment, but this is what we did in Berlin, as we put the urn with Jens' ashes in the ground in front of a mulberry tree in the municipal cemetery 2009. Family and friends all around in a big circle, everybody would come for a moment in front of the tree and throw a hand full of earth (a little letter, a little flower) in the hole, say goodbye.

In Thnol Lok we were saying goodbye to Jens, to the victims of the Khmer Rouge terror and to each other. Planting the trees was not sad in itself, on the contrary, I had the impression that the villagers enjoyed this moment, and seeing the two little bodhy trees standing next to the stupa was a joyful moment for me too. Finally, we went up on the hill, only few of us and Kakkda. This was my farewell, this was the tree, deep in my heart, that I dedicated to Jens - and I'm sure that other people who came up were thinking the same thing: the bodhy tree up there is Jens' tree in Thnol Lok. There is a marvellous view up there, you can see the mountains around and greet the horizon. Goodbye Thnol Lok. 


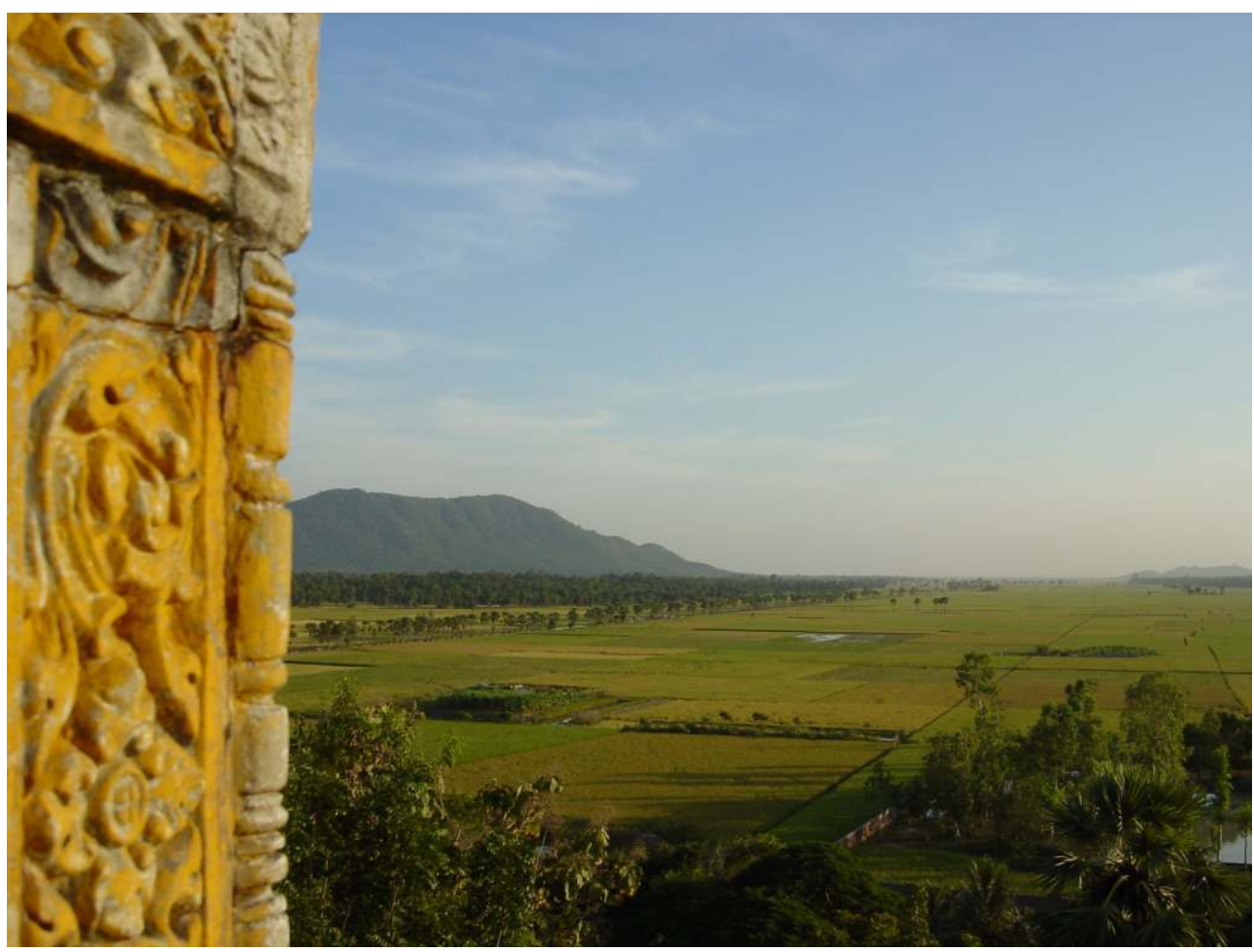

Photo by Julian Poluda (2008)

\section{The Case of Grandma Nhey}

12 Grandma Nhey is one of the old women who lost her husband and children under Pol Pot. At the time she was very happy to be interviewed by the young Mr Ra in a white skirt and to be filmed by Kakkda. She said incredibly simple and wise words about the Khmer Rouge: "They looked like anyone of us, but they acted differently"; "They were villagers like us, but they became Pol Pot"; "They followed their law, their law was to kill". 
This media file cannot be displayed. Please refer to the online document http:// journals.openedition.org/anthrovision/1502

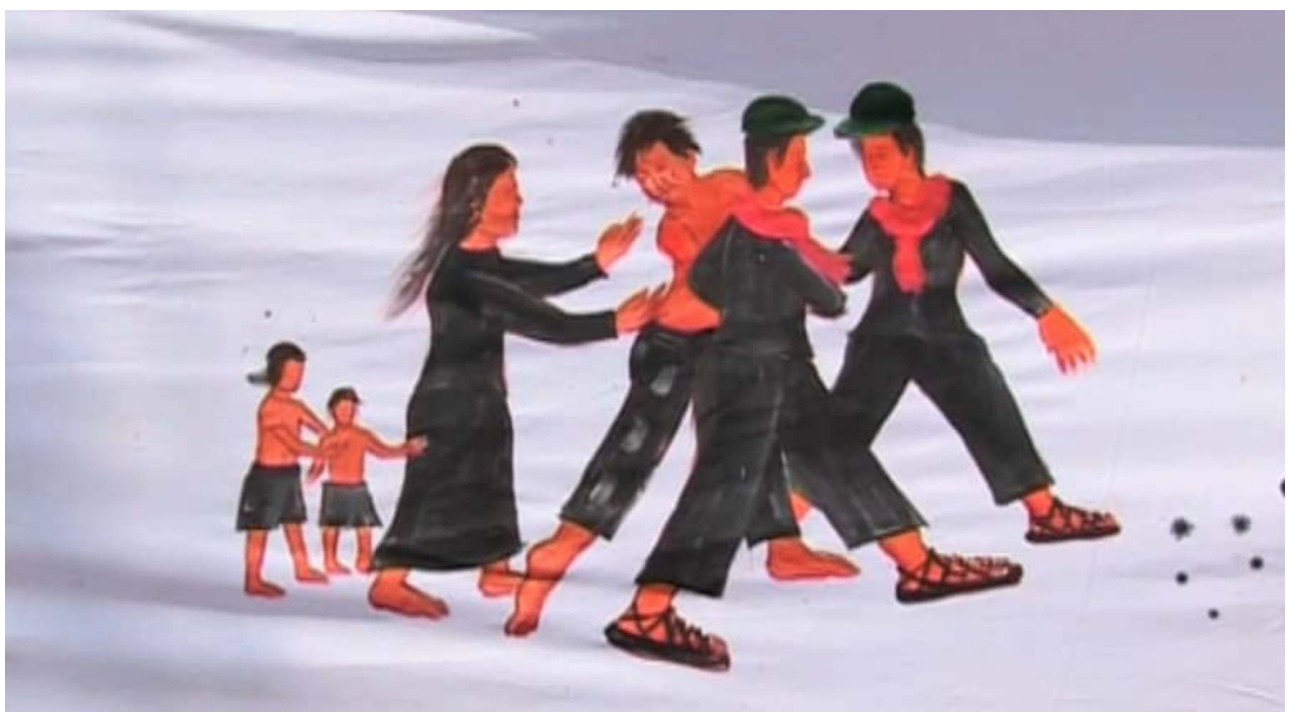

Link: https://player.vimeo.com/video/141045679

Video extract by Ella Pugliese (2015) from We Want (U) To Know by Ella Pugliese, Nou Va and the villagers (2009)

As we visited Grandma Nhey right after our arrival, we told her that her story has moved many people around the world. And then it happened again. The conversation with her continued, and our Cambodian colleagues translated our questions but not what she replied, so that it was only weeks later when I discovered that her position towards her participation in the project was controversial to say the least. What a surprise! Our main protagonist, whose example had always raised compassion, acknowledgement and respect in the public was distancing herself from the film! The old woman whose story had often been taken as an example of how deep such a process can go, ${ }^{10}$ was telling the camera that she felt uneasy that her miserable fate been shown all over the place! We listened again and again to this passage with Va, as I could not believe it. Not that she would repudiate the work and her decision to go back to the pagoda where her husband was taken away from her. But she said she felt so miserable because she had lost him and because she was so lonely, while other women still had their husband or had found a new one. The comparison with the "heile Welt'11, I realized, seems to be still very painful.

This is something that I understand very well: as Jens suddenly died I felt like I had been knocked from the sunny side of the road to the dark one. Anouk was asking again and again why she had no dad anymore, while everybody else did have one. We felt different from the others around us, we felt miserable. This is, of course, only one side of the despair one meets when losing a loved one all of a sudden. It is a significant aspect of trauma: we feel that we do not fit in our world anymore; we tend to think that we are the only ones who happen to be bereaved. We feel lonely and abandoned. 


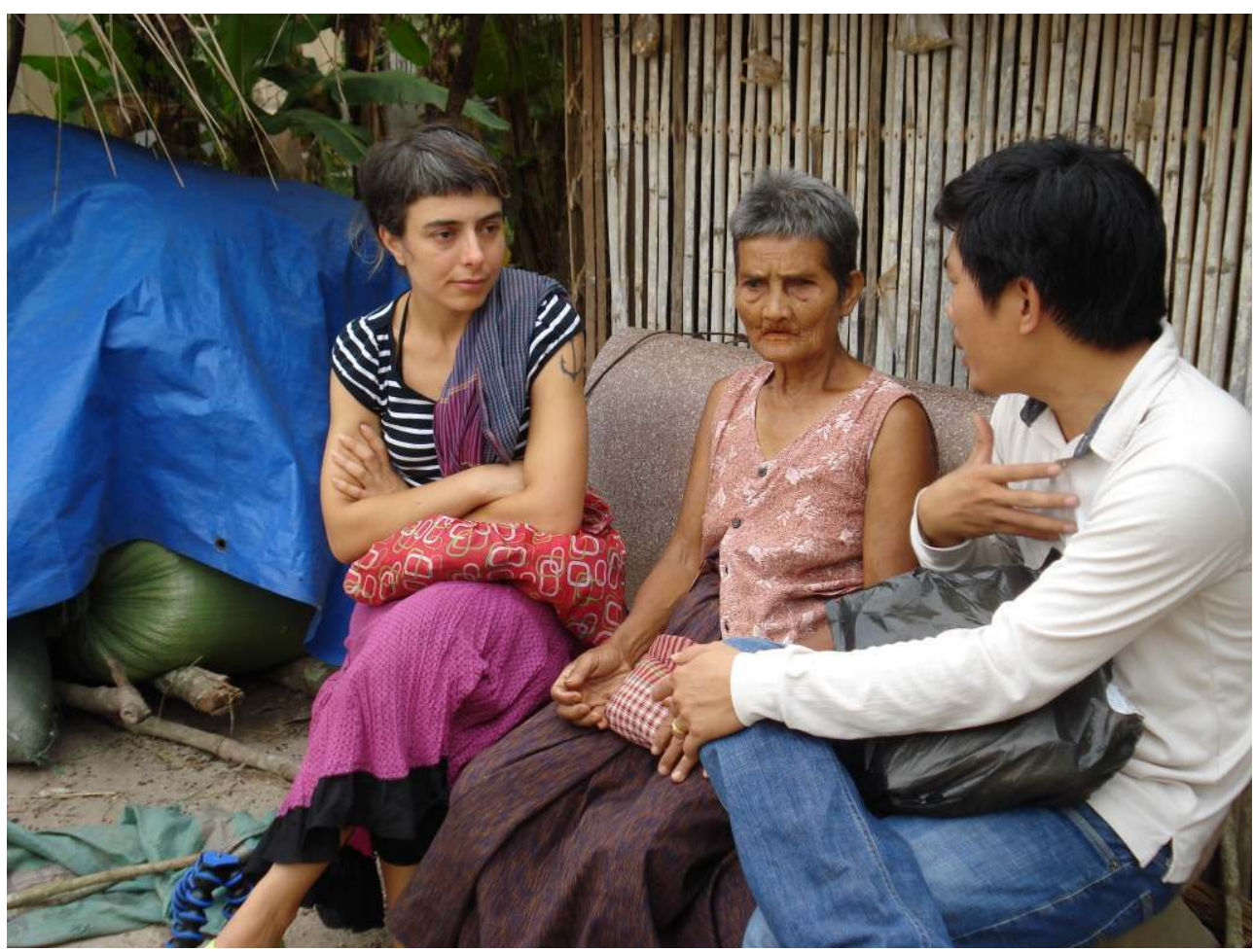

Photo by Judith Strasser (2012)

Luckily enough, we had the chance to talk to Grandma Nhey again twice: directly after watching the film at night and the following day. Grandma at night:

"I am happy, but my happiness is in my suffering. [...] Happiness and suffering are both contained in my heart. [...] When we see the film we feel released but we don't forget, we still keep it in our heart." The next day:

"Everybody has to die, but for example my husband died in very bad conditions. If they die with care and dignity it is good... [.... I still feel regret, but what can we do if they passed away already? We can't take them back. [...] I am grateful to be in the film, now the villagers are proud of me. They said: you were a good actor! They felt pity, before they did not know but now they know. They laughed and admired me and felt compassion."

Her considerations show the complexity of grief, and that nothing can be accomplished while mourning; it is a non-linear process, which can accompany us for the rest of our lives, depending on our cultural background and spiritual orientation. I cannot identify with Grandma Nhey but I know I learned a lot from her. In 2008 I was impressed by her courage as she asked us to take her back to Cheu Theal pagoda, near Kampot, almost two hours ride from Thnol Lok by car. When we picked her up early in the morning she was dressed up in her best clothes as if for a ceremony. Some of her relatives were coming with us in order to play her scene. I remember the happy mood during the trip. And I remember my wonder and admiration as she explained the details of the scene, how the Khmer Rouge arrived and took her husband away, and her irritation, as the female actor could not scream adequately. I had the idea that she could scream herself, counterpointing the scene with her presence and her voice. It worked. I remember this serious, calm expression in her eyes at the end, I imagined her thinking: "I have done 
what I had to." I remember Jens and I talking about that later: how incredible it was, that we had the chance to accompany this old woman all together to the most horrible place in her life. She must have felt that this act of shared remembrance would be good for her. she must have simply sensed something positive in going back and going through once again.

This media file cannot be displayed. Please refer to the online document http:// journals.openedition.org/anthrovision/1502

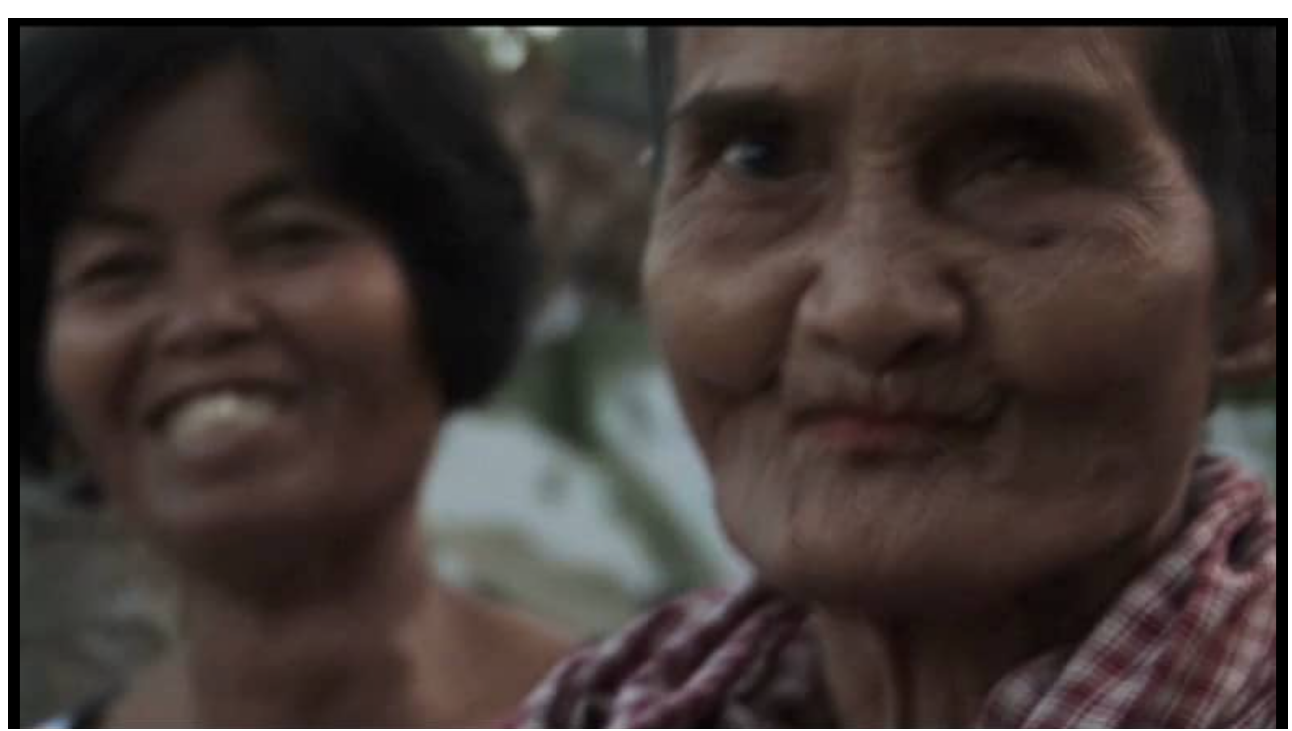

Link: https://player.vimeo.com/video/141045677

Video extract by Ella Pugliese (2015) from We Want (U) To Know by Ella Pugliese, Nou Va and the villagers (2009)

16 There are as many different ways and different paths to cope with bereavement as there are bereaved people, and I think that each person has to look for the one which is best for her/him. But deep in our hearts Jens and I shared the belief that it is good to confront the past, to go through in order to go further. 


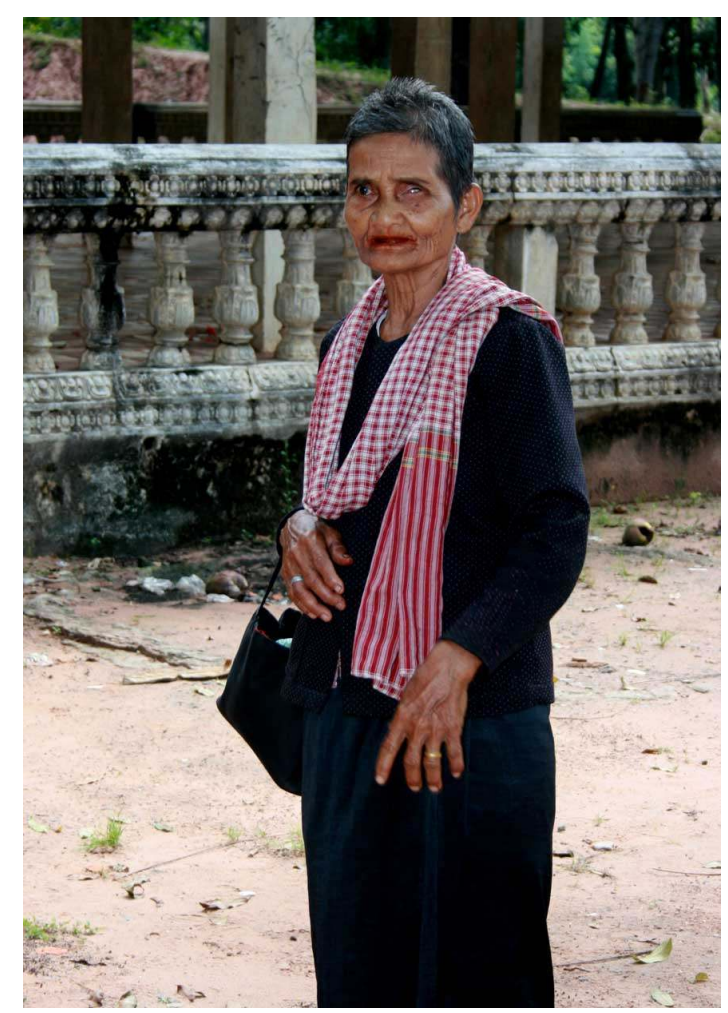

Photo by Leah Roth-Howe (2008)

I start to change perspective: I had the chance to share painful experiences of loss with very special people, shortly before I myself experienced death in its brutality: the accident may be, instead of something bad, what seemed to be a sinister/eerie/dire/dreadful coincidence at first, is becoming a chance and a challenge. ${ }^{12}$.

After watching WWU2K at the night screening in April 2012, Grandma Nhey realised that she was right to know how important it was for her to show up. She had the opportunity to feel recognized and even admired by her own community ${ }^{13}$. Furthermore, she expressed the importance of care-full support in the case of complicated grief ${ }^{14}$ :

"If the film team had not come back", she stressed, "people would say: you see, they arrived, made their project and disappeared... But no, they came again after so long, they care, they offer to the monks with us... so we feel good, like a clear sky."

\section{A Politics of Hope}

It is Denzin who talks about auto-ethnography as articulating a politics of hope: "Hope is the desire to dream, the desire to change, the desire to improve human existence" (Denzin 2003: 263). 


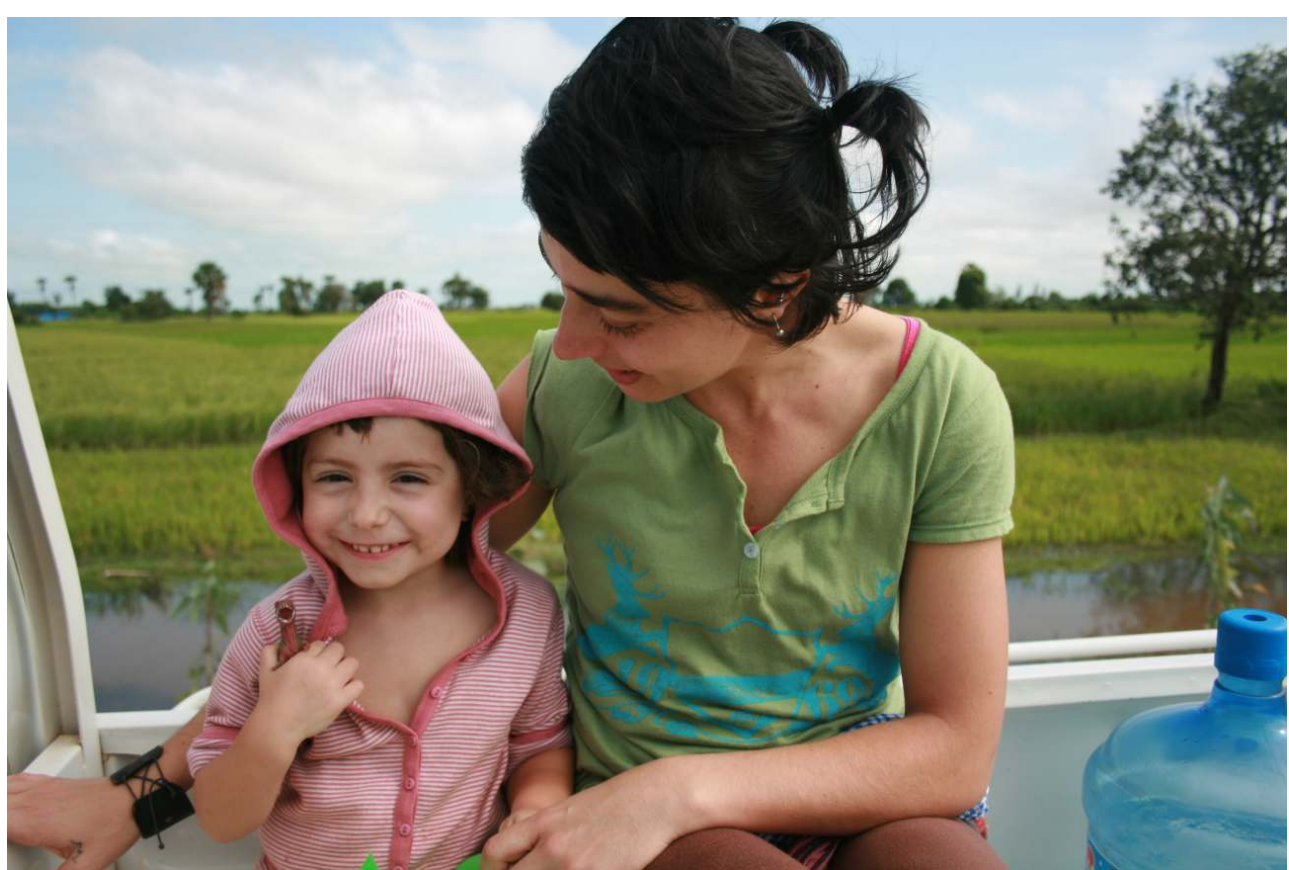

Photo by Leah Roth-Howe (2008)

As I left Cambodia in 2009 in shock, I had all the typical 'symptoms' of trauma following violent death; accidents, together with murder and suicide, are often labelled as violent death. I was completely upside down - again the language: how can I say it in tidy understandable words? - well I was kind of driven mad. Not that I did anything crazy. I am a mother, and it seems like I have some kind of attachment to this life, and this earth, enough to keep me at least alive even when the world suddenly goes upside down. No sense of reference anymore, to be more exact:

No sense at all.

Not anymore.

Die heile Welt was forever gone. It had been before. At once life was before and after. The pain was a constant state of the everyday life, the everyday life: unacceptable. Everything unacceptable. I still do not accept what happened, I will never accept that somebody dies for nothing, like nothing, now here, in a few minutes gone. Gone forever. Gone like he goes on the street, he goes and goes, he walks in the night walks and never comes back. How can you accept that a young strong lively talented sexy pale arrogant explosive crazy beautiful inscrutable tall irascible huge-eyes huge-ears thousand-and-one-moles sweetest dad sweetest lover some man some boy some guy somebody, somebody dies? Dies like that? Dies like if he was angry with you and he dies? 


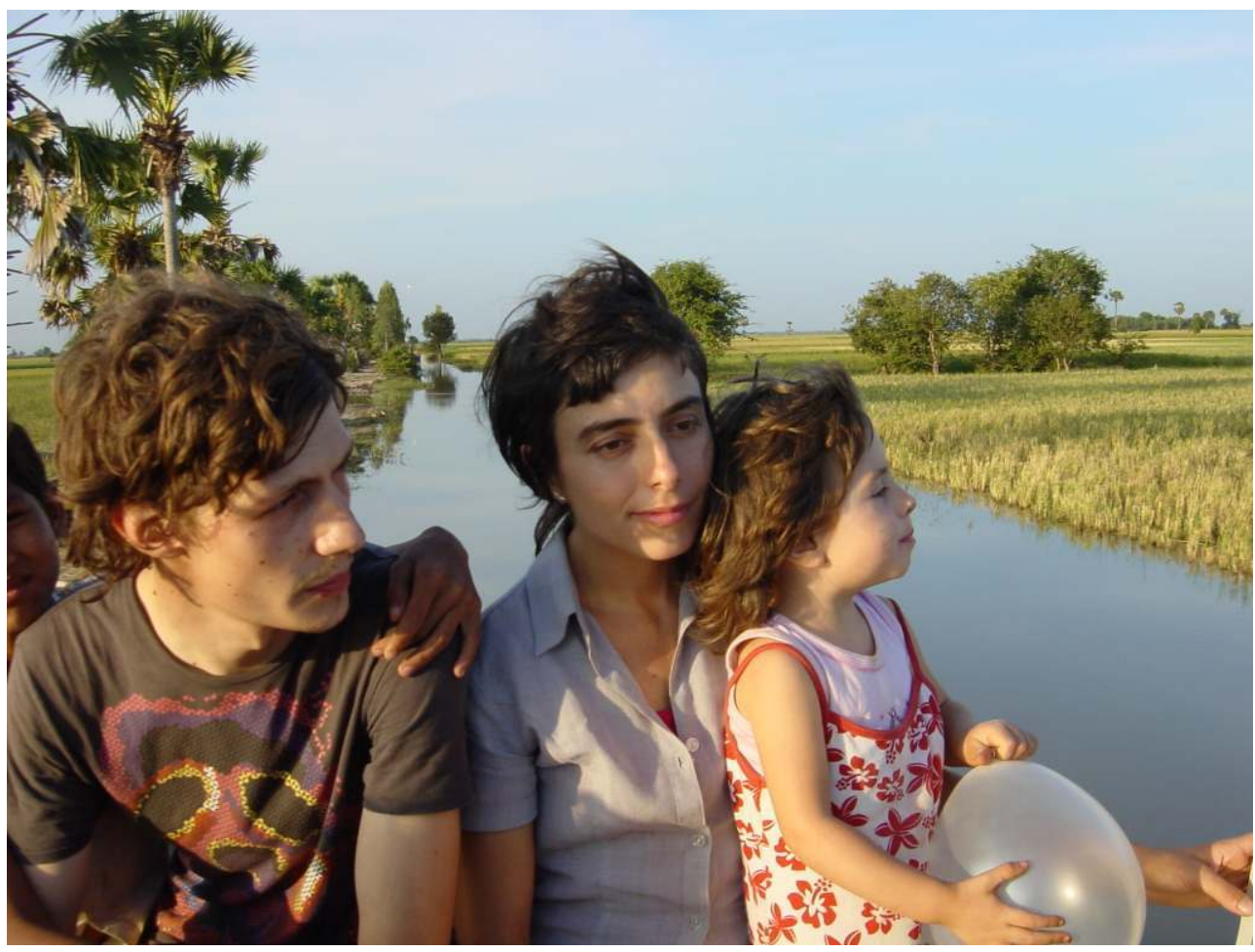

Photo by Julian Poluda (2008)

When you look at me

you should see a tall smart shadow

behind me

This is not a scream of desperation.

This is a desperate cry for love. Of love.

The point is not to accept this, it is not accepting death and forgetting the loved one. The point is to accept love, this desperate love - forever. Forever as long as we live and remember.

Memory seems to be necessary. Imperative.

In this post-modern world, which runs so quick that we loose our stories without even noticing $\mathrm{it}^{15}$, we need an act of remembrance. It has to be a personal act, but it can be and some time it should be also a public one- a shared one.

Collective memory should embrace and welcome personal acts of remembrance, reflecting the uniqueness of death, bereavement and grief. Through remembering we could better understand, that we all have only this life as long as we are here. And that we share the same destiny, as simple as it is, we all die.

But first, we live.

30 This is my wish for a politics of hope. 


\section{Going Through - Going Further? The Missing Chapter}

31 It really looks like there will be a missing chapter in this article. It is the chapter of my own going back, not to Thnol Lok, this time, but to Kampot, one week later. Kampot is the sleepy, quiet town by the river, near the sea, between the beautiful mountains where the Khmer Rouge used to hide in the caves. It is the place where Jens died.

The missing chapter is the one about him dying there, of me going back there, filming, looking for the bridge, not finding it, finding it at last-not recognizing it.

No, Anouk, this is not the bridge. Let's go further.

We did, we went further, but there were no other small bridges around, this was the place - only, I did not recognize it. I had it fixed quite differently in my memories. The bridge. Such an awful bridge. Such an awful place to die.

The missing chapter would have been about going back, as if nothing had happened, people chatting, everything normal, the world did not stop at the time, why should it stop now? Going through means maybe that: taking the same path which broke our life forever without feeling pain -- not feeling anything.

\section{This media file cannot be displayed. Please refer to the online document http://} journals.openedition.org/anthrovision/1502

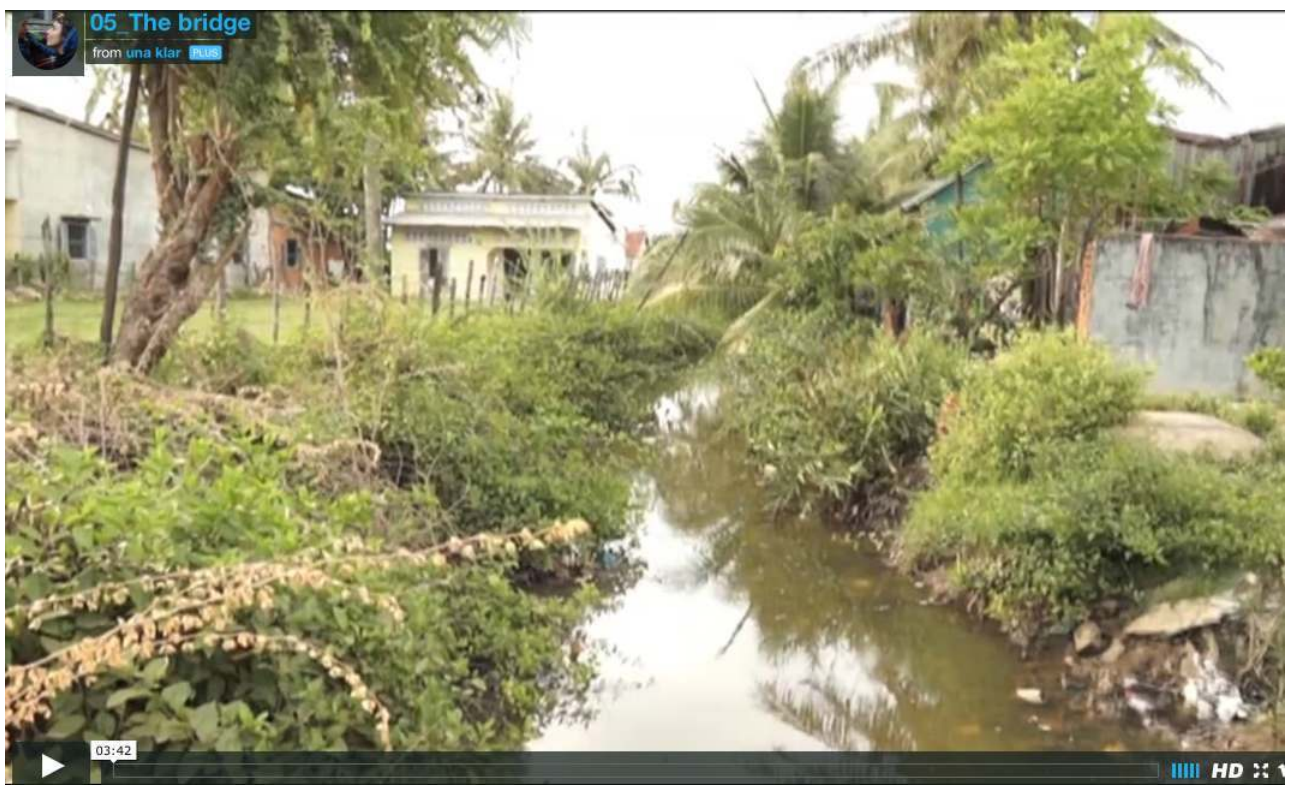

Link: https://player.vimeo.com/video/141045678

Video by Ella Pugliese (2015)

The missing chapter is missing because I believe that one may go through once again in order to take distance from the pain and look ahead. But I don't know yet if I did, what it was, how it was for me. This is the book, or the chapter, or actually the film that I have not written nor edited yet. I may start tomorrow. I may do it soon. 
In this missing chapter there will be a special place for the importance of rituals and eventually re-inventing rituals. I think that the attachment to the past has to be active CREATIVE smiling POETIC.

The missing chapter is this ghost of a chapter for now, a smiling ghost maybe, one which hides/shows itself in photos at least ${ }^{16}$.

\section{Ghost Birthdate cake}
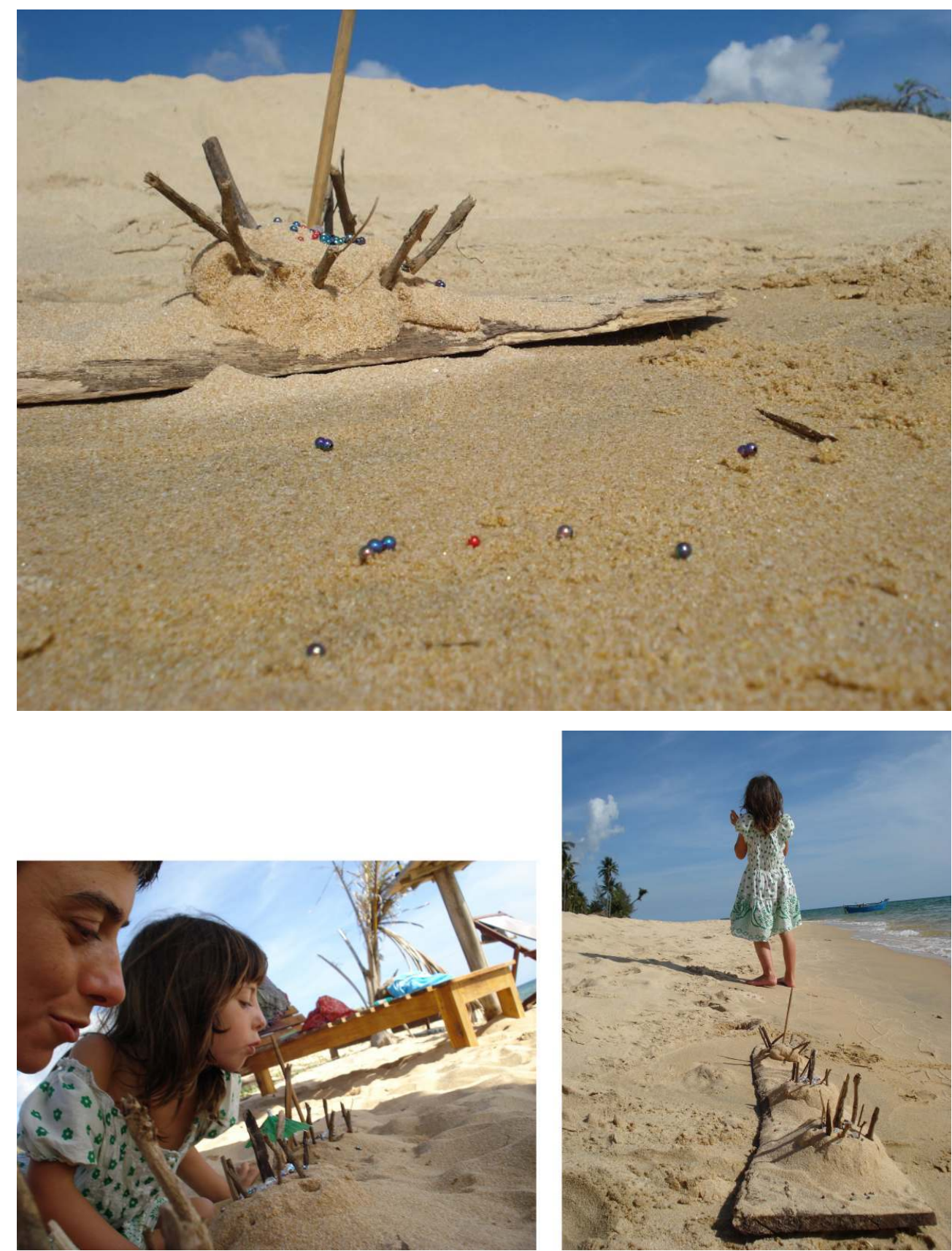

Photo by Ella Pugliese (17 April 2012) 


\section{Conclusions}

\section{The mountains around Thnol Lok}

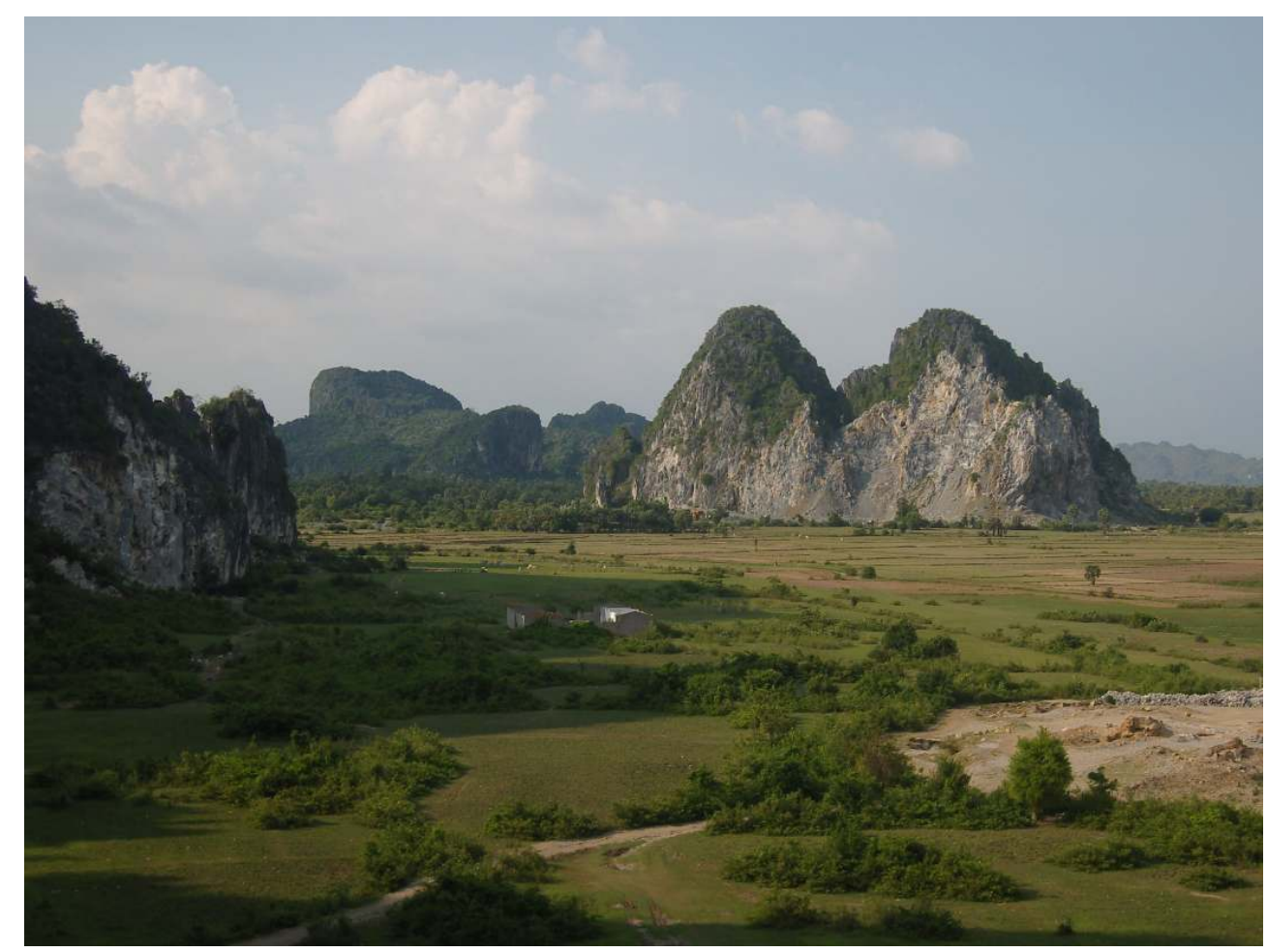

Photo by Julian Poluda (2008) 
Ella and Anouk after talking with Grandma Nhey in Thnol Lok

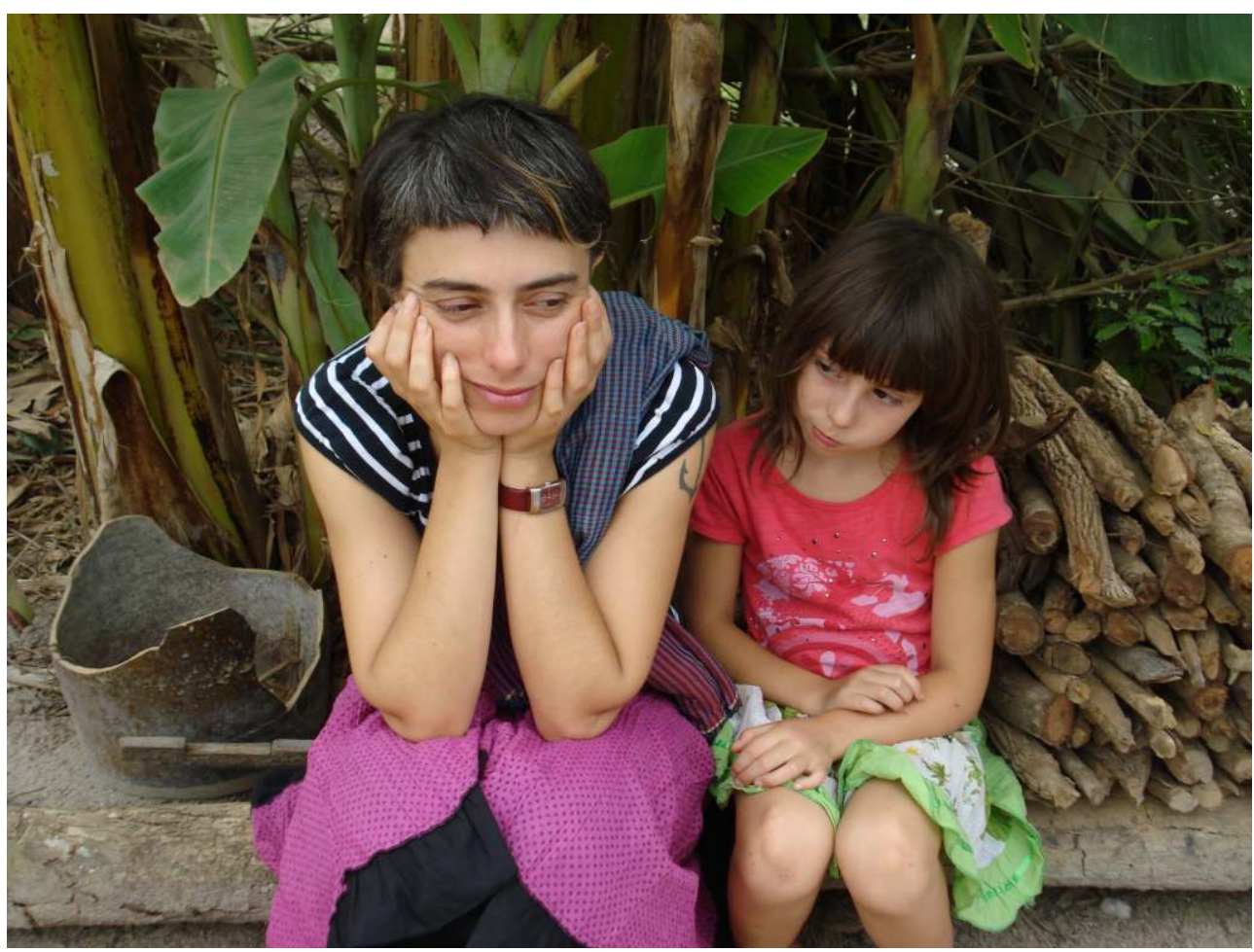

Photo by Judith Strasser (2012)

\section{BIBLIOGRAPHY}

\section{Books and Papers}

Agger Inger,. 2015. Calming the mind: Healing after mass atrocity in Cambodia, Transcult Psychiatry 2015, Feb 4.0 (0):1 - 18. http://tps.sagepub.com/content/ early/2015/02/04/1363461514568336.long

Alsop, Christiane Kraft. 2002. Home and Away: Self-Reflexive Auto-/Ethnography. Forum Qualitative Sozialforschung / Forum: Qualitative Social Research, 3(3), Art.10

Behar, Ruth. 2003. Ethnography and the Book That Was Lost. Ethnography, March 2003, Vol.4.1, SAGE Journals.

Caruth, Cathy. ed. 1995. Trauma. Explorations in Memory. Baltimore, John Hopkins University Press.

Denzin, Norman K. 2003. Performing [Auto] Ethnography Politically. The Review of Education, Pedagogy and Cultural Studies. 23:257-278

Eisenbruch, Maurice. 1991. From Post-Traumatic Stress Disorder to Cultural Bereavement: Diagnosis of Southeast Asian Refugees. Social Science \& Medicine 33(6): 673-680. 
Caruth (Ed.), Trauma. Explorations in Memory (pp. 13 - 60). Baltimore, John Hopkins University Press

Guillou, Anne Y. 2012. An alternative memory of the Khmer Rouge genocide: The dead of the mass graves and the land guardian spirits (neak ta). South East Asia Research 20(2): 207-226.

Mallon, Brenda. 2008. Dying, Death and Grief. London: SAGE Publications.

Rosaldo, Renato. 2004. Grief and a Headhunter's Rage. In: A. C. G. M. Robben (Ed.) Death, Mourning and Burial: A Cross-Cultural Reader (pp. 167- 178). Oxford, Blackwell.

Films

Pugliese, Ella, Nou Va, and the Villagers of Thnol Lok, dir. 2011. We Want (U) To Know. KID

(production). 54 min. TRAILER: https://www.youtube.com/watch?v=SY0D8nugnrY

\section{NOTES}

1. Khmer for 'mute'

2. That's how she called our friend Gregor Matuschek in Berlin at the time!

3. As Rosaldo says, talking about the parallels between the loss of his wife and research colleague in the field and the specific form of grief that he experienced among the older Ilongot men of northern Luzon in the Philippines, "Ilongot anger and my own overlap, rather like two circles, partially overlaid and partially separate. They are not identical." (Rosaldo 2004: 171).

4. And for the first time in the new, shorter version

5. Khmer for 'foreigner'. Va and some other Cambodians were in the filming from the beginning, but we, the barang, did not want to appear in a story which we felt it was not ours-yet. Later I realized it was a rather weak side of our participatory work, not to show our 'pale face'.

6. Buddhist layman.

7. Meanwhile I am familiar with this kind of ritual as I have participated in it at different times during my last visit to Cambodia in 2014. It is a bangsoekool, a gift-bestowingl ritual, based on ritual donations to the monks and a particular form of rhythmic chanting. "This chanting follows the rhythm of the breath and is held by many Cambodians to have a powerful, calming effect on the audience (...). This is done to placate both the minds of the living and the spirits of the dead." Agger 2015: 9.

8. In the consultation with monks and villagers it turned out that we would plant not one but three trees! Two at the sides of the stupa in memory of the victims of Democratic Kampuchea, one on the upper hill, by the old pagoda, where normally only the monks go to pray as it is too high to climb for the elderly, and the chief monk keeps a garden of rare plants and trees.

9. In the countryside people tend to call the Khmer Rouge simply "Pol Pot".

10. At the end of the film she says that she feels better now, "Now we are happy again, now we can let go".

11. Can be translated as the ideal or even idyllic world. It is rather a philosophical concept, the world in its fullness, the world before rupture and bereavement.

12. As in the case of famous ethnographer Renato Rosaldo, the sudden, unexpected loss of his wife in the field revealed retrospectively the deep, hidden sense of what we were working on: "I began to fathom the force of what Ilongot had been telling me about their losses through my own loss" (Rosaldo 2004: 170).

13. This underlines the importance of sustainable planning of the work, which is specially true in case of PV - if it is not possible to build an independent film laboratory or a stable working group, 
then it becomes absolutely necessary to 'go back', ideally every now and then, but at least once some time after.

14. "Complicated grief is usually defined as grief which does not diminish over time; the intensity of emotions remain high and it interferes with normal functioning." (Mallon 2008: 152) 15. "I told stories I didn't think were in me to tell. (...) This idea, that ethnography is about finding stories we don't know we have lost..." Behar 2003: 2

16. In 2014 I went back to Cambodia again to collect materials for this 'ghost of a film'. I have been filming, doing interviews, writing, but once back in Berlin I put everything in a beautiful drawer where it remains, waiting for the right moment to come out. For this reason I decided not to change this chapter yet. Nevertheless I'd like to add a new trace: I have discovered that "neak ta is a spirit which, for some reason, has not been transformed into the spirit of a dead person sent to the island of the dead, and therefore cannot be reborn. In this way, it is similar but not identical to those who have died a bad death, those who have committed suicide, been murdered, drowned, struck by lightning, or have died in childbirth. Those who have died a bad death are called 'uncooked ghost' (...) first because they have not been cremated and second because they do not belong to the village anymore. (...) In sum, the dead of the mass graves can easily be 'elected' as neak ta due to their bad death in violent and terrifying circumstances." (Guillou 2012: 223-224). Based on Cambodian beliefs, Jens had a bad death, like the Khmer Rouge victims, and may have turned into the Neak Ta of the bridge, or the Neak Ta of the tree next to the bridge. But in this way he would stay by the bridge, what is not possible, as he has also a tree in Berlin and many other places where we look for him and find him... another suggestion, another trace to follow.

17. "Paradoxes, I believe, are the most fruitful states of mind," writes Alsop (Alsop 2002: 31), and I absolutely agree!

\section{ABSTRACTS}

As a filmmaker I worked on trauma, loss and mourning in Cambodia from 2008 to 2009, and made a participatory documentary with survivors of the Khmer Rouge Regime. At this time I too experienced violent death in an immediate and personal way, when my beloved partner was killed in an accident. In this article, drafted after I returned from that first visit, I reflect on this private loss, and attempt to analyse and transform it creatively through a public process in which emotions are re-appropriated.

En tant que cinéaste, j'ai travaillé entre 2008 et 2009, sur les notions de trauma, de perte et de deuil au Cambodge et j'ai réalisé un documentaire participatif avec les survivants au régime Khmer Rouge. Simultanément, j'ai été confrontée personnellement et d'une manière directe à la mort accidentelle de mon partenaire. Dans cet article, esquissé après être revenue de cette première visite, je réfléchis à cette perte personnelle et essaye de l'analyser et de la transformer en créativité grâce à une dynamique publique au cours de laquelle on peut se réapproprier les émotions.

Como cineasta, trabajé sobre el trauma, la pérdida y el duelo en Camboya entre 2008 y 2009 y realicé un documental participativo con supervivientes del régimen de los jemeres rojos. En esa época también viví la muerte violenta de una forma inmediata y personal, cuando mi pareja 
murió en un accidente. En este artículo, escrito después de volver de esa primera visita, reflexiono sobre esa pérdida privada e intento analizarla y transformarla creativamente a través de un proceso público en el que se recuperan las emociones.

\section{INDEX}

Keywords: Cambodia, auto-ethnography, death, trauma theory, ethnography of loss and mourning, Khmer Rouge

Palabras claves: Cambodia, auto-etnografía, muerte, teoría del trauma, etnografía de la pérdida y del luto, Jemeres rojos

Mots-clés: Cambodge, auto-ethnographie, théorie du trauma, ethnographie de la perte et du deuil, Khmer Rouge

\section{AUTHOR}

\section{ELLA PUGLIESE}

unaklar@gmail.com

Ella Pugliese (Rome, 1974) has a degree in Languages and a MA in Anthropology of Migration. She lives and works in Berlin as a freelance Author and Filmmaker. In the past years she has collected field experiences in refugee and Roma camps from Naples to Algeria, she has worked for international research institutes dealing with migration issues and she has collaborated with the Department of Performing Arts of the University Roma Tre, as well as with RAI-Sat TV. She has co-directed photographed and edited several documentary projects with an anthropological focus. 